\title{
Development of Effective Lipase-Hybrid Nanoflowers Enriched with Carbon and Magnetic Nanomaterials for Biocatalytic Transformations
}

\author{
Renia Fotiadou ${ }^{1}$, Michaela Patila ${ }^{1}$, Mohamed Amen Hammami ${ }^{2}$, Apostolos Enotiadis ${ }^{2}$, \\ Dimitrios Moschovas ${ }^{3}$, Kyriaki Tsirka ${ }^{3}$, Konstantinos Spyrou ${ }^{3}$, Emmanuel P. Giannelis ${ }^{2}$, \\ Apostolos Avgeropoulos ${ }^{3}$ (D), Alkiviadis Paipetis ${ }^{3}$, Dimitrios Gournis ${ }^{3}([)$ and \\ Haralambos Stamatis 1 ,* \\ 1 Biotechnology Laboratory, Department of Biological Applications and Technologies, University of Ioannina, \\ 45110 Ioannina, Greece; renia.fotiadou@gmail.com (R.F.); mpatila@cc.uoi.gr (M.P.) \\ 2 Department of Materials Science and Engineering, Cornell University, Ithaca, NY 14853, USA; \\ mah424@cornell.edu (M.A.H.); ae276@cornell.edu (A.E.); epg2@cornell.edu (E.P.G.) \\ 3 Department of Materials Science and Engineering, University of Ioannina, 45110 Ioannina, Greece; \\ dmoschov@cc.uoi.gr (D.M.); tsirka.kyriaki@gmail.com (K.T.); konstantinos.spyrou1@gmail.com (K.S.); \\ aavger@uoi.gr (A.A.); paipetis@uoi.gr (A.P.); dgourni@uoi.gr (D.G.) \\ * Correspondence: hstamati@uoi.gr; Tel.: +30-265-100-7116
}

Received: 20 April 2019; Accepted: 23 May 2019; Published: 28 May 2019

\begin{abstract}
In the present study, hybrid nanoflowers (HNFs) based on copper (II) or manganese (II) ions were prepared by a simple method and used as nanosupports for the development of effective nanobiocatalysts through the immobilization of lipase B from Pseudozyma antarctica. The hybrid nanobiocatalysts were characterized by various techniques including scanning electron microscopy (SEM), energy dispersion spectroscopy (EDS), X-ray diffraction (XRD), Raman spectroscopy, and Fourier transform infrared spectroscopy (FTIR). The effect of the addition of carbon-based nanomaterials, namely graphene oxide and carbon nanotubes, as well as magnetic nanoparticles such as maghemite, on the structure, catalytic activity, and operational stability of the hybrid nanobiocatalysts was also investigated. In all cases, the addition of nanomaterials during the preparation of HNFs increased the catalytic activity and the operational stability of the immobilized biocatalyst. Lipase-based magnetic nanoflowers were effectively applied for the synthesis of tyrosol esters in non-aqueous media, such as organic solvents, ionic liquids, and environmental friendly deep eutectic solvents. In such media, the immobilized lipase preserved almost $100 \%$ of its initial activity after eight successive catalytic cycles, indicating that these hybrid magnetic nanoflowers can be applied for the development of efficient nanobiocatalytic systems.
\end{abstract}

Keywords: hybrid nanoflowers; lipase; magnetic nanomaterials; biocatalysis; enzyme immobilization

\section{Introduction}

Over the last decades, the immobilization of enzymes onto nanostructured supports has been extensively used and has facilitated their applications, owing to their easy handling and operational stability, as well as facile recovery and reusability of the biocatalysts, leading to more efficient bioprocesses [1,2]. Various nanostructured composite materials with extensive active surface areas and desirable pore sizes, such as nanoporous supports, nanofibers, nanoparticles, and carbon-based nanomaterials (e.g., nanotubes and graphene) have been proven to be effective in manipulating the nanoscale environment of biomolecules [3-5] and, as a consequence, their biological function and stability. 
Organic-inorganic hybrid nanomaterials (nanoflowers) are a recently developed group of nanoparticles that schematically resemble plant flowers in a nanoscale range [6]. Hybrid nanoflowers (HNFs) have attracted a lot of interest over the last years as host platforms for immobilizing enzymes, owing to the higher surface-to-volume ratio compared to spherical nanoparticles, as well as to their simple, eco-friendly, and cost-effective synthesis [7,8]. Nanoflowers containing various enzymes have been usually prepared as enzyme- $\mathrm{Cu}_{3}\left(\mathrm{PO}_{4}\right)_{2} \cdot 3 \mathrm{H}_{2} \mathrm{O}$ hybrids by combining copper sulfate $\left(\mathrm{CuSO}_{4}\right)$ with enzymes in phosphate-buffer saline (PBS). Different HNFs mainly based on copper (II) and calcium (II) ions have been used to form complexes with enzymes and other proteins [9-11]. Moreover, the development of protein-embedded HNFs based on other metal ions, such as zinc (II), cobalt (II), and iron (II), was recently reported [12-14]. The formation of HNFs comprises the following steps: the nucleation and formation of primary crystals, the growth of these aggregates, and the complete formulation of nanoflowers [8]. During the first step, protein molecules form complexes with metal ions, primarily through the coordination between nitrogen atoms of the amide groups present in the protein backbone and the metal ion. These complexes provide sites for nucleation. The intramolecular interactions between the metal ion and the protein promote the anisotropic growth of nano-petals (step 2) and, consequently, the formation of a flower-like structure in which proteins serve as the glue that binds the petals together (step 3). The formation of these enzyme-embedded HNFs do not require harsh conditions and toxic reactants for their self-assembly; thus, the immobilization procedure is facilitated with biomolecules in a one-step process. Moreover, the incorporated enzyme is subjected to minor manipulation in comparison with other conventional immobilization procedures, thus retaining its biocatalytic activity [8].

The selection of the enzyme and the metal ions-as well as the $\mathrm{pH}$, the temperature, and the incubation time-plays an essential role for the configuration and the catalytic efficiency of the enzyme-containing nanoflowers $[8,15]$. A variety of enzymes with biotechnological interest have been encapsulated in HNFs and successfully applied in dye decolorization [11,16], the production of esters [17], the detection of phenols or glucose [9,18], the degradation of pollutants [19], and the development of biosensors $[20,21]$ in which two or more enzymes were successfully encapsulated in the same nanoflower.

The enhanced activity of enzymes that is observed in various HNFs is mainly attributed to their high surface area, which decreases mass-transfer limitations, along with the specific interactions of the enzyme molecules and metal ions $[8,22,23]$. However, the biocatalytic activity and stability of some HNFs are reduced by the interactions between metal ions and proteins [24]. Recently, it was proposed that the incorporation of surfactants [25], biopolymers such as chitosan [26], and carbon-based nanomaterials $[27,28]$ could enhance the catalytic properties as well as the mechanical strength of enzyme-containing nanoflowers, leading to stable nanohybrids.

Herein, we describe the preparation of novel hybrid nanoflowers consisting of copper (II) or manganese (II) ions, combined with magnetic nanoparticles and carbon-based nanomaterials, and we investigate their use as versatile host platforms for the development of sufficient systems for the immobilization of enzymes. The addition of carbon-based nanomaterials, namely graphene oxide and multi-walled carbon nanotubes, in the preparation of nanoflowers is expected to provide high surface area and extraordinary mechanical properties, whereas the incorporation of magnetic nanoparticles, such as maghemite, allows the easy and quick separation of the nanoflowers by the application of an external magnetic force. The use of these novel HNFs as host platforms for the immobilization of lipase B from Pseudozyma antarctica, an enzyme with numerous biotechnological applications, was investigated. The novel nanobiocatalysts were characterized by scanning electron microscopy (SEM), energy dispersion spectroscopy (EDS), X-ray diffraction (XRD), Raman spectroscopy, and Fourier transform infrared spectroscopy (FTIR), while the effect of the composition of nanoflowers on the catalytic activity, thermal activity, and operational stability of the immobilized enzyme was investigated. Moreover, the ability of the lipase-based nanoflowers to catalyze the synthesis of lipophilic derivatives 
of phenolic antioxidants, such as tyrosol, in non-aqueous media, as well as in environmental-friendly ionic solvents, was also investigated.

\section{Materials and Methods}

\subsection{Materials}

Lipase B from Pseudozyma antarctica (formerly Candida antarctica, CaLB) was purchased from Novozymes A/S (Bagsværd, Denmark) and was utilized without further purification. 4-nitrophenyl butyrate ( $p$-NPB), 4-nitrophenol ( $p$-NP), copper (II) sulfate pentahydrate, manganese (II) sulfate, tyrosol, and dimethyl sulfoxide were obtained from Sigma-Aldrich (St. Louis, MO, USA). Vinyl butyrate was obtained from Fluka. The ionic liquid (IL) 1-Butyl-3-methylimidazolium hexafluorophosphate ([BMIM] $\mathrm{PF}_{6}$ ) with a purity of $97.0 \%$ was purchased from Sigma-Aldrich (St. Louis, MO, USA). Choline chloride $(\mathrm{ChCl})$ and urea $(\mathrm{U})$ were obtained from Sigma-Aldrich (St. Louis, MO, USA) and used for the preparation of deep eutectic solvents (DES), according to a previous work [17]. All organic solvents used were of analytical grade.

\subsection{Preparation of CaLB Nanoflowers}

The CaLB hybrid nanoflowers were prepared according to Ge et al. [8]. Typically, $0.42 \mathrm{~mL}$ of $\mathrm{CuSO}_{4}$ or $\mathrm{MnSO}_{4}$ aqueous solutions $(120 \mathrm{mM})$ were added to $50 \mathrm{~mL}$ of phosphate buffer saline (PBS $1 X$, $\mathrm{pH}$ 7.4), which contained $0.4 \mathrm{mg} \mathrm{mL}^{-1} \mathrm{CaLB}$. The mixtures were placed for incubation at $25^{\circ} \mathrm{C}$ for 3 days. The nanoflower precipitates were separated by centrifugation at $4000 \mathrm{rpm}$ for $10 \mathrm{~min}$, washed three times with distilled water, and dried under vacuum over silica gel at room temperature. Nanoflowers were stored at $4{ }^{\circ} \mathrm{C}$ until used. The prepared copper- and manganese-based samples are labeled $\mathrm{Cu}_{3}\left(\mathrm{PO}_{4}\right)_{2}$ and $\mathrm{Mn}_{3}\left(\mathrm{PO}_{4}\right)_{2}$, respectively.

For the preparation of nanomaterials-modified CaLB nanoflowers, a similar approach was followed. Graphene oxide (GO), oxidized multi-walled carbon nanotubes (CNTs), and maghemite nanoparticles $\left(\gamma-\mathrm{Fe}_{2} \mathrm{O}_{3}\right)$ were synthesized as reported elsewhere [29-31]. Briefly, $5 \mathrm{mg}$ of GO and $3 \mathrm{mg}$ of oxidized CNTs or $\gamma-\mathrm{Fe}_{2} \mathrm{O}_{3}$ nanoparticles were added in $49 \mathrm{~mL}$ of PBS and sonicated for $20 \mathrm{~min}$.

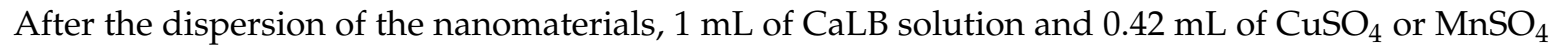
aqueous solutions $(120 \mathrm{mM})$ were added into the mixture. The next steps were the same as those described previously. Nanoflowers containing only GO or CNTs were also prepared. The prepared modified copper-based samples are labeled GO-Cu $\left(\mathrm{PO}_{4}\right)_{2}, \mathrm{CNTs}-\mathrm{Cu}_{3}\left(\mathrm{PO}_{4}\right)_{2}, \mathrm{GO} / \mathrm{CNTs}-\mathrm{Cu}_{3}\left(\mathrm{PO}_{4}\right)_{2}$, and $\mathrm{GO} / \mathrm{Fe}_{2} \mathrm{O}_{3}-\mathrm{Cu}_{3}\left(\mathrm{PO}_{4}\right)_{2}$, and the prepared modified manganese-based samples are labeled GO- $\mathrm{Mn}_{3}\left(\mathrm{PO}_{4}\right)_{2}$, CNTs-Mn $3\left(\mathrm{PO}_{4}\right)_{2}, \mathrm{GO} / \mathrm{CNTs}-\mathrm{Mn}_{3}\left(\mathrm{PO}_{4}\right)_{2}$, and GO/Fe $2 \mathrm{O}_{3}-\mathrm{Mn}_{3}\left(\mathrm{PO}_{4}\right)_{2}$.

\subsection{Characterization of CaLB Nanoflowers}

SEM images were acquired from a JEOL JSM-5600 microscope (JEOL Ltd., Tokyo, Japan) with 10 and $25 \mathrm{kV}$ accelerating voltage. Moreover, the surface morphologies of the samples were determined by field emission scanning electron microscopy (FE-SEM) using a SEM Zeiss Gemini 500 (Oberkochen, Germany). Prior to SEM analysis, the nanoflowers were placed in double-sided carbon tape and sputter-coated with gold-platinum. Phase elemental distribution was studied with SEM/EDS (JEOL JSM-6510 LV equipped with an X-Act EDS-detector by Oxford Instruments, Abingdon, Oxfordshire, UK).

The XRD patterns of all CaLB-HNFs were collected on a D8 Advance Bruker diffractometer with $\mathrm{Cu} \mathrm{K} \alpha$ radiation $(40 \mathrm{kV}, 40 \mathrm{~mA})$ and a secondary-beam.

Raman spectrocopy was used to confirm the presence of the carbon nanomaterials in the nanomaterials-modified CaLB-HNFs. The Raman spectra were recorded with the Labram HR system by HORIBA Scientific (HORIBA, Paris, France). The 514.5 green line of an air cooled Ar-Ion Laser was employed for the Raman excitation using a confocal aperture of 100 . The laser power at the focal plane of the x100 objective was circa $0.8 \mathrm{~mW}$. Spectral treatment included only a linear baseline subtraction. 
FTIR was utilized to confirm the successful immobilization of CaLB in the nanoflower structure. The spectra were recorded in the range of $400-4000 \mathrm{~cm}^{-1}$ using a FTIR-8400 infrared spectrometer (Shimadzu, Tokyo, Japan) equipped with a deuterated triglycine sulfate (DTGS) detector. For each sample, a total of 64 scans were averaged, using a $2 \mathrm{~cm}^{-1}$ resolution. The samples were prepared using $\mathrm{KBr}$ pellets containing a circa $2 \mathrm{wt} \%$ sample. The similarity of FTIR spectra in the Amide I region (1600-1700 $\mathrm{cm}^{-1}$ ) was quantified by calculation of the correlation coefficient, $\mathrm{r}$, using the following equation:

$$
r=\frac{\sum x i y i}{\sqrt{\sum x i^{2} \Sigma y i^{2}}},
$$

where $x$ and $y$ represent the spectral absorbance values of the reference and sample spectra, respectively, at the $i$ th frequency position [32]. For identical spectra, the $r$ value is equal to 1.0, while spectra that have differences will show lower values.

\subsection{Determination of Encapsulation Yield}

The amount of the immobilized CaLB was determined by calculating the protein concentration present in the supernatant after the immobilization procedure using the Bradford assay [33]. Enzyme encapsulation was estimated as the difference between the initial amount of the enzyme and the amount of the enzyme in the supernatant after immobilization.

\subsection{Activity of CaLB Nanoflowers}

The activity of CaLB-HNFs was determined by the hydrolysis of $p$-NPB. Specifically, $0.5 \mathrm{mg}$ of CaLB nanoflowers was added into $2 \mathrm{~mL}$ of phosphate buffer $(50 \mathrm{mM}, \mathrm{pH} 7.5)$. The reaction was initiated with the addition of $20 \mu \mathrm{L}$ of a $50 \mathrm{mM} p$-NPB solution (dissolved in DMSO), and the mixture was incubated for up to $10 \mathrm{~min}$ at $40{ }^{\circ} \mathrm{C}, 650 \mathrm{rpm}$. The 4-Nitrophenol ( $p$-NP) release was monitored at $405 \mathrm{~nm}$. The activity was estimated by measuring the concentration of $p$-NP using a standard curve. In this work, one unit of lipase activity was defined as the specific quantity of CaLB nanoflowers required to hydrolyze $1 \mu \mathrm{mol}$ of $p$-NPB per reaction minute. Blank measurements without any enzyme were also incubated with the substrate for ten minutes, and their absorbance was measured where no catalytic activity was observed.

\subsection{Stability of CaLB Nanoflowers}

The thermal stability of free CaLB and CaLB-HNFs was tested at $60{ }^{\circ} \mathrm{C}$ for up to $24 \mathrm{~h}$ in phosphate buffer (50 mM, pH 7.5). In order to determine the remaining activity of CaLB nanoflowers, aliquots were taken at predetermined interval times for measuring the remaining lipase activity. The remaining hydrolyzing activity was estimated as described before, monitoring the increase in the absorbance of $p$-NP.

\subsection{Transesterification of Tyrosol Catalayzed by CaLB Nanoflowers}

The performance of CaLB-HNFs was tested on their ability to synthesize tyrosol esters. Typically, tyrosol $(20 \mathrm{mM})$, vinyl butyrate $(100 \mathrm{mM})$, and $4 \mathrm{mg} \mathrm{mL}^{-1}$ of CaLB-HNFs were added in various organic solvents and ionic liquids. The reaction mixtures were incubated for $72 \mathrm{~h}$ under stirring at $50{ }^{\circ} \mathrm{C}$. Synthesis reactions were repeated twice, while experiments without nanoflowers were also conducted, and any decrease in the amount of tyrosol was observed for the selected solvents. The concentration of tyrosol in the reaction mixtures was quantified by high performance liquid chromatography (HPLC), equipped with a $\mu$ Bondapack C18 reverse phase column (particle size $10 \mu \mathrm{m}$, length $300 \mathrm{~mm}$, diameter $3.9 \mathrm{~mm}$ ) and a diode array UV detector. The elution was carried out with $40 \%$ water (containing $0.1 \%$ acetic acid) in methanol at a flow rate of $1 \mathrm{~mL} \mathrm{~min}^{-1}$ for $30 \mathrm{~min}$. Tyrosol and its ester derivative were detected at $280 \mathrm{~nm}$, while the column temperature was set at $35^{\circ} \mathrm{C}$. The conversion yield of the 
enzymatic transesterification was based on the decrease in the concentration of tyrosol, which was calculated using a tyrosol standard curve.

\subsection{Reusability of CaLB Nanoflowers}

The reusability of CaLB-HNFs was tested with respect to $p$-NPB hydrolysis for nine consecutive cycles. After each catalytic cycle, the samples were recovered by centrifugation at $1000 \mathrm{rpm}$ for $2 \mathrm{~min}$ and excessively rinsed out three times with phosphate buffer (50 mM, pH 7.5). In the case of $\mathrm{GO} / \mathrm{Fe}_{2} \mathrm{O}_{3}$-based hybrid nanoflowers, an external magnetic field was applied after each cycle and between washing procedures. The relative activity (\%) was defined as the ratio of the remaining activity to the activity of the first cycle.

Magnetic hybrid nanoflowers ( $\mathrm{GO} / \mathrm{Fe}_{2} \mathrm{O}_{3}$-basedHNFs) were tested for their reusability on the transesterification of tyrosol in tert-butyl-methylether. Tyrosol $(20 \mathrm{mM})$, vinyl butyrate $(100 \mathrm{mM})$, and $4 \mathrm{mg} \mathrm{mL}^{-1}$ of $\mathrm{GO} / \mathrm{Fe}_{2} \mathrm{O}_{3}$ CaLB-HNFs were added in $1 \mathrm{~mL}$ tert-butyl-methylether, and the reaction mixture was incubated for $72 \mathrm{~h}$ under stirring at $50{ }^{\circ} \mathrm{C}$. The nanobiocatalytic system was separated from the reaction solution by an external magnetic field and washed twice with $1 \mathrm{~mL}$ of tert-butyl-methylether. The modified nanoflowers were applied to a new reaction solution and tested as described before for eight successive cycles.

\section{Results and Discussion}

\subsection{Morphological and Structural Characterization of CaLB Nanoflowers}

In the present work, HNFs based on copper (II) or manganese (II) ions were prepared by a simple method and used as nanosupports for the encapsulation of lipase B from Pseudozyma antarctica (CaLB). The effect of the enrichment of HNFs with graphene oxide sheets, oxidized multi-walled carbon nanotubes, and $\gamma-\mathrm{Fe}_{2} \mathrm{O}_{3}$ nanoparticles on the morphological, structural, and catalytic properties of HNFs was investigated.

SEM images of unmodified $\mathrm{Cu}_{3}\left(\mathrm{PO}_{4}\right)_{2} \mathrm{CaLB}-\mathrm{HNF}$ s revealed a high quality nanoflower formation with diameters in the range of 15-30 $\mu \mathrm{m}$ (Figure 1a). Moreover, SEM images of unmodified $\mathrm{Mn}_{3}\left(\mathrm{PO}_{4}\right)_{2}$ CaLB-HNFs (Figure 1b) displayed a flower-like structure, though this structure was not as clear as in the case of $\mathrm{Cu}_{3}\left(\mathrm{PO}_{4}\right)_{2}$. The nanomaterials-modified CaLB-HNFs, either with GO, CNTs, or both carbon structures together, exhibited different structures and formations, as indicated in Figure 1c-j, while a more detailed analysis can be found in the Supplementary material (Figure S1). It is noteworthy to add that the presence of carbon nanostructures (either GO or CNTs) in manganese-based nanoflowers facilitated the formation of nanoflowers in the final structures compared to the unmodified one (Figure 1g-j). Moreover, the combination of GO and CNTs resulted in the growth of clear crystals forming particular porous flower-like structures.

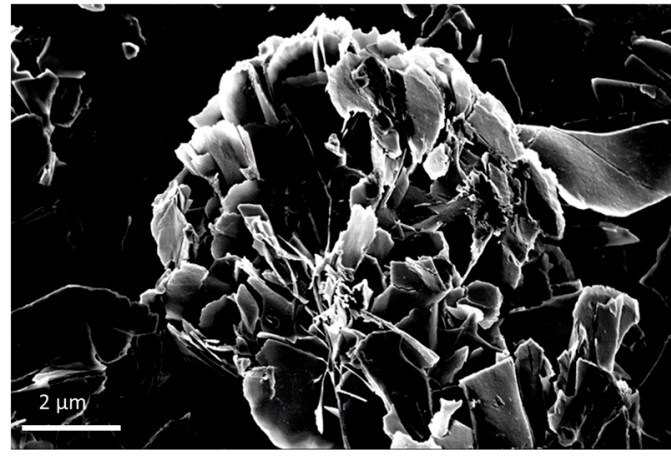

(a)

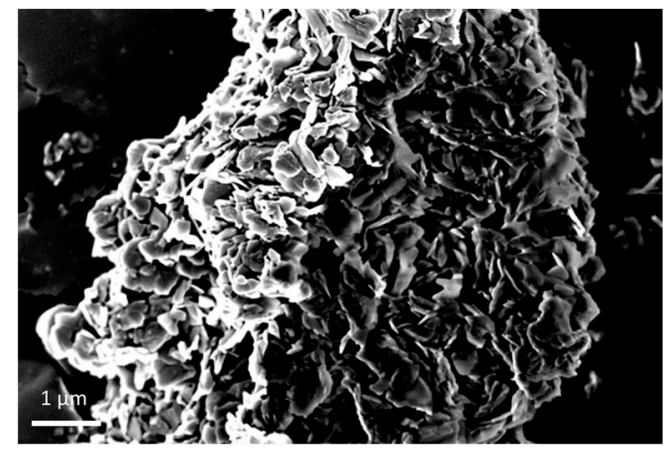

(b)

Figure 1. Cont. 


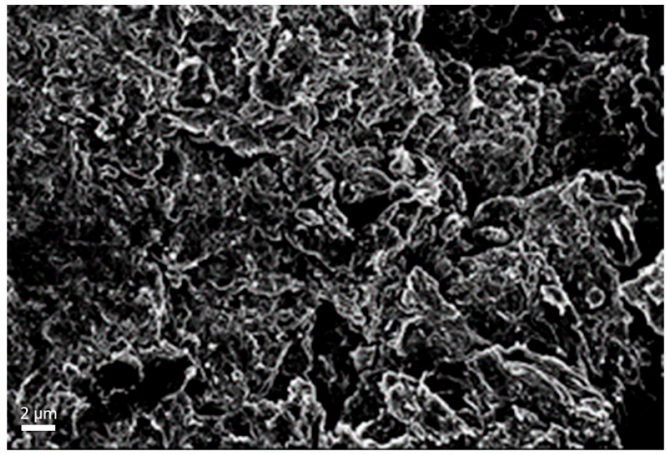

(c)

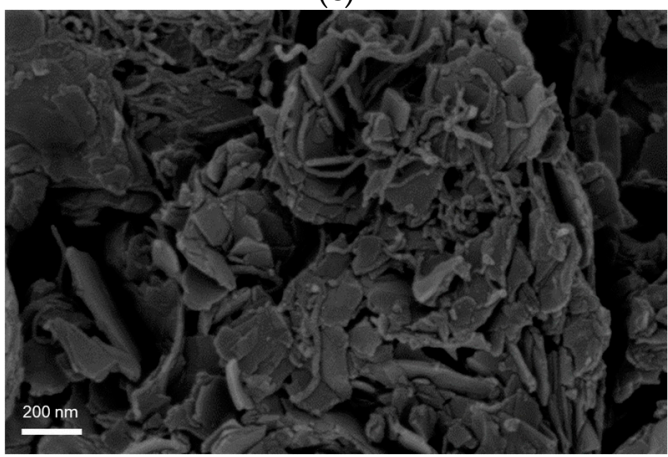

(e)

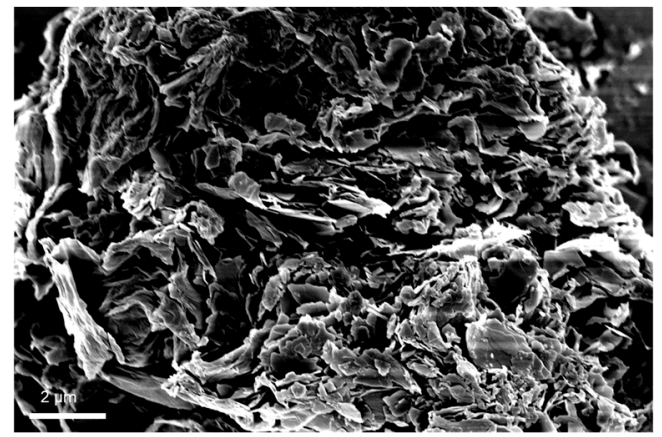

(g)

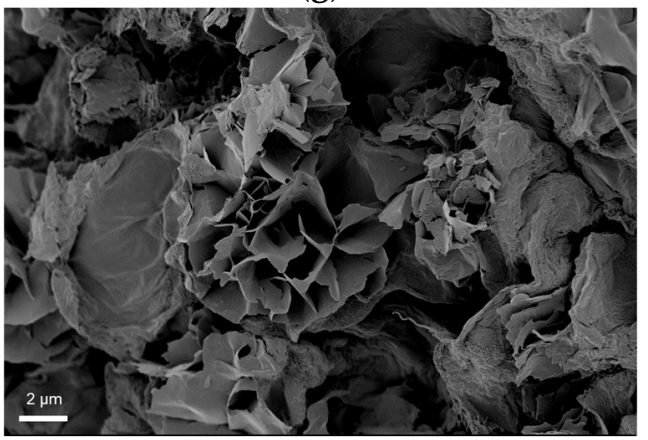

(i)

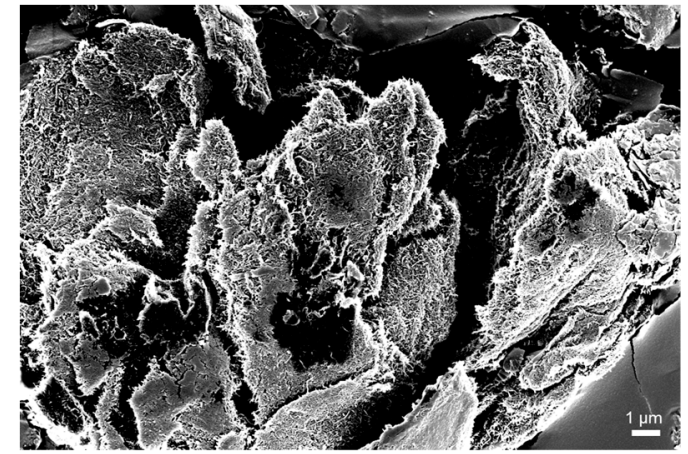

(d)

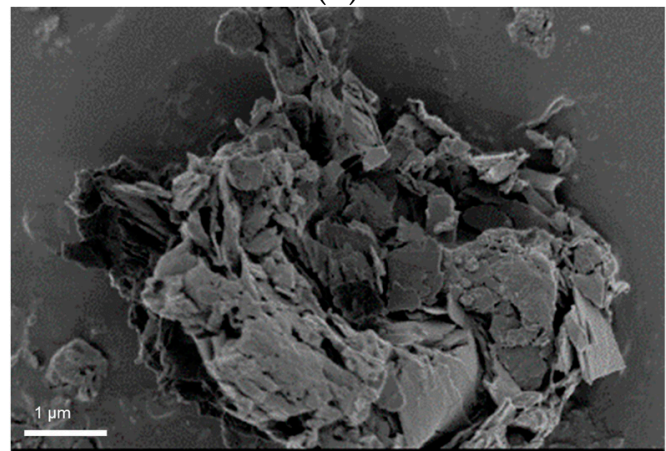

(f)

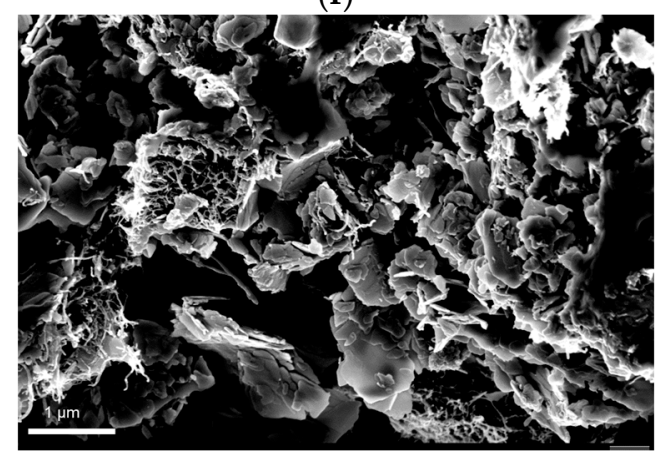

(h)

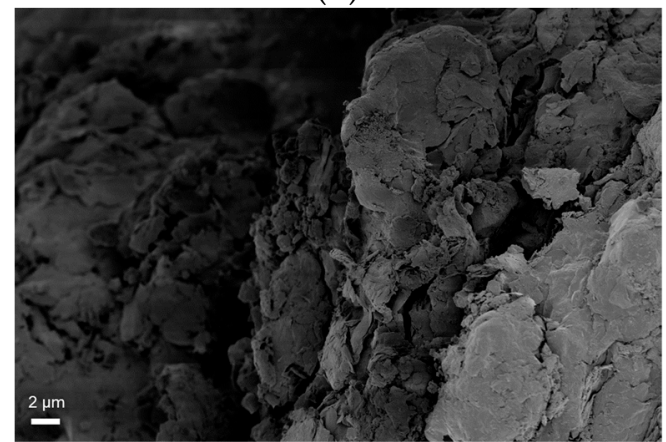

(j)

Figure 1. SEM images of: (a) unmodified $\mathrm{Cu}_{3}\left(\mathrm{PO}_{4}\right)_{2}$ CaLB-HNFs; (b) unmodified $\mathrm{Mn}_{3}\left(\mathrm{PO}_{4}\right)_{2}$ CaLB-HNFs; (c) GO-Cu$\left(\mathrm{PO}_{4}\right)_{2}$ CaLB-HNFs; (d) CNTs-Cu $\left(\mathrm{PO}_{4}\right)_{2}$ CaLB-HNFs; (e) GO/CNTs-Cu $3\left(\mathrm{PO}_{4}\right)_{2}$ CaLB-HNFs; (f) GO/Fe $\mathrm{O}_{3}-\mathrm{Cu}_{3}\left(\mathrm{PO}_{4}\right)_{2} \mathrm{CaLB}-\mathrm{HNF}$; (g) GO-Mn ${ }_{3}\left(\mathrm{PO}_{4}\right)_{2}$ CaLB-HNFs; (h) CNTs-Mn $3\left(\mathrm{PO}_{4}\right)_{2}$ CaLB-HNFs; (i) GO/CNTs-Mn $3\left(\mathrm{PO}_{4}\right)_{2}$ CaLB-HNFs; and (j) $\mathrm{GO} / \mathrm{Fe}_{2} \mathrm{O}_{3}-\mathrm{Mn}_{3}\left(\mathrm{PO}_{4}\right)_{2}$ CaLB-HNFs.

Modified $\mathrm{GO} / \mathrm{Fe}_{2} \mathrm{O}_{3}$-based $\mathrm{HNFs}$ were further elementally analyzed using energy dispersion spectroscopy (EDS) (Figure S2). The peaks of carbon (C) and oxygen (O) were attributed to CaLB 
and the incorporated nanomaterials, while the presence of nitrogen $(\mathrm{N})$ and sulfur $(\mathrm{S})$ confirmed the successful encapsulation of the enzyme in the nanoflower structure. The appearance of copper $(\mathrm{Cu})$ (Figure S2a), manganese (Mn) (Figure S2b) and phosphate (P) peaks indicated the successful formation of the nanoflowers. Sodium $(\mathrm{Na})$ and chloride $(\mathrm{Cl})$ peaks appeared due to the utilized preparation buffer. Moreover, the confirmation of the presence of iron nanoparticles $(\mathrm{Fe})$ in the hybrid nanoflower structures was also observed-the atomic percentages of iron were 4.34 and $5.42 \%$ in the cases of $\mathrm{GO} / \mathrm{Fe}_{2} \mathrm{O}_{3}-\mathrm{Cu}_{3}\left(\mathrm{PO}_{4}\right)_{2}$ and $\mathrm{GO} / \mathrm{Fe}_{2} \mathrm{O}_{3}-\mathrm{Mn}_{3}\left(\mathrm{PO}_{4}\right)_{2} \mathrm{HNFs}$, respectively (Table S1).

$\mathrm{X}$-ray diffraction $(\mathrm{XRD})$ was used to characterize the unmodified and the nanomaterials-modified CaLB-HNFs, and the XRD patterns are provided in the Supplementary material (Figure S3). For the copper-based CaLB-HNFs, the XRD patterns represented peaks for the $\mathrm{Cu}_{3}\left(\mathrm{PO}_{4}\right)_{2} \cdot 3 \mathrm{H}_{2} \mathrm{O}(\mathrm{JCPDS}$ 00-022-0548) phase, while for the manganese-based CaLB-HNFs, the phase of manganese changed from $\mathrm{Mn}_{3}\left(\mathrm{PO}_{4}\right)_{2}$ for the unmodified nanoflowers to $\mathrm{Mn}_{2} \mathrm{P}_{2} \mathrm{O}_{7}$ for the nanomaterials-modified HNFs [34].

The presence of the carbon-based nanostructures in the CaLB-HNFs was confirmed with Raman spectroscopy. The Raman spectra of the unmodified $\mathrm{Cu}_{3}\left(\mathrm{PO}_{4}\right)_{2} \mathrm{CaLB}-\mathrm{HNFs}$ and $\mathrm{Mn}_{3}\left(\mathrm{PO}_{4}\right)_{2}$ CaLB-HNFs, as well as the modified HNFs with GO, CNTs, and $\gamma-\mathrm{Fe}_{2} \mathrm{O}_{3}$, are presented in Figure 2. The spectrum of the unmodified $\mathrm{Cu}_{3}\left(\mathrm{PO}_{4}\right)_{2} \mathrm{CaLB}-\mathrm{HNFs}$ presented several vibrational modes; the most pronounced were located at $645 \mathrm{~cm}^{-1}, 927 \mathrm{~cm}^{-1}$, and $1147 \mathrm{~cm}^{-1}$ and can be attributed to the antisymmetric bending of the $\mathrm{PO}_{4}{ }^{3-}$ ion, the symmetric stretching vibrations of $\mathrm{PO}_{4}{ }^{3-}$ ion, and the antisymmetric stretching vibrations of the $\mathrm{PO}_{4}{ }^{3-}$ ion, respectively [35]. The unmodified $\mathrm{Mn}_{3}(\mathrm{PO} 4)_{2}$ CaLB-HNFs presented a strong vibrational mode at $958 \mathrm{~cm}^{-1}$ that can be ascribed to the symmetric stretching mode of the $\mathrm{PO}_{4}{ }^{3-}$ ion [36].

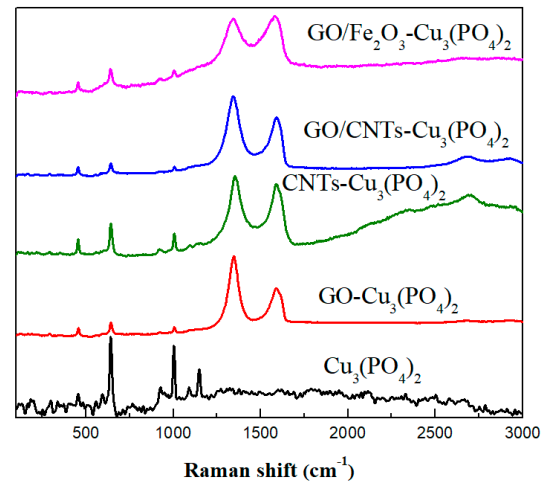

(a)

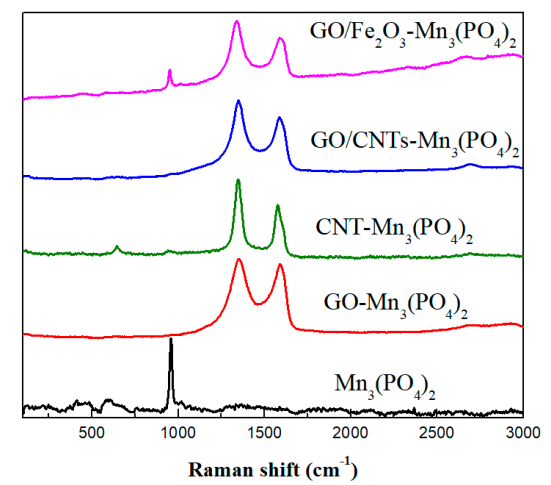

(b)

Figure 2. Raman spectra of: (a) $\mathrm{Cu}_{3}\left(\mathrm{PO}_{4}\right)_{2}$-based CaLB-HNFs and (b) $\mathrm{Mn}_{3}\left(\mathrm{PO}_{4}\right)_{2}$-based CaLB-HNFs.

The preparation of $\mathrm{Cu}_{3}\left(\mathrm{PO}_{4}\right)_{2}$ - and $\mathrm{Mn}_{3}\left(\mathrm{PO}_{4}\right)_{2}$-based CaLB-HNFs with GO in both led to the appearance of the characteristic of carbon-based materials vibrational modes, D and G, located at circa $1346 \mathrm{~cm}^{-1}$ and $1590 \mathrm{~cm}^{-1}$, respectively [37], while a weak asymmetric $2 \mathrm{D}$ vibrational mode was also present in both cases at around $2685 \mathrm{~cm}^{-1}$ [38]. Similarly, the preparation of both ion-based CaLB-HNFs with CNTs led to the appearance of the characteristic D and G vibrational modes located at circa $1350 \mathrm{~cm}^{-1}$ and $1587 \mathrm{~cm}^{-1}$, respectively, while the 2D vibrational mode of the CNTs was located at circa $2700 \mathrm{~cm}^{-1}$. The more intense $\mathrm{D}$ and $\mathrm{G}$ vibrational modes were also present when both $\mathrm{GO}$ and CNTs were added in the CaLB-HNFs, establishing the successful incorporation of the carbonaceous nanomaterials into the HNFs.

To confirm the successful immobilization of CaLB in the 3D nanostructures, all nanobiocatalytic systems were characterized by FTIR spectroscopy by recording the spectra in the range $400 \mathrm{~cm}^{-1}$ to $4000 \mathrm{~cm}^{-1}$. As seen in Figure 3, peaks at the region 950 to $1060 \mathrm{~cm}^{-1}$ were associated with the asymmetric stretching vibrations of $\mathrm{PO}_{4}{ }^{3-}$, while peaks at the region $550 \mathrm{~cm}^{-1}$ to $650 \mathrm{~cm}^{-1}$ arose from the bending vibrations of bridging phosphate groups, such as O-P-O $[39,40]$. The presence of CaLB in 
the nanoflower structure was confirmed by the peak at $1648 \mathrm{~cm}^{-1}$, which arises from the stretching vibrations of $\mathrm{C}=\mathrm{O}$ of the peptide chain of the enzyme and corresponds to the Amide I band [41,42].

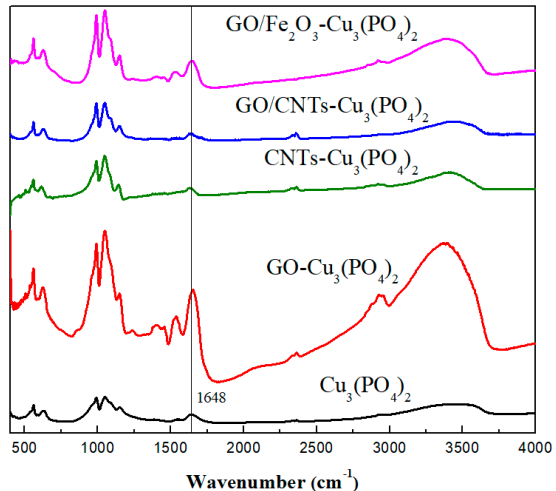

(a)

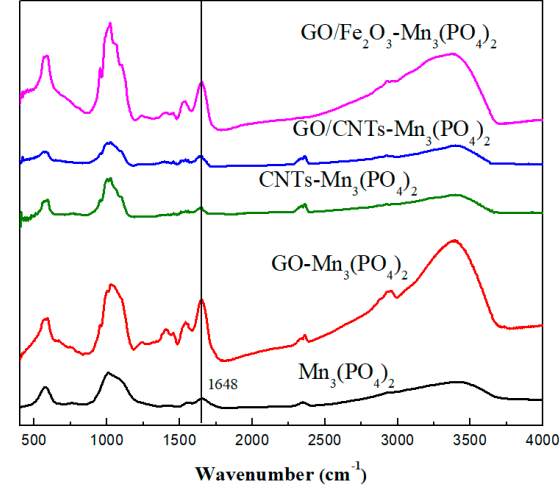

(b)

Figure 3. FTIR spectra of: (a) $\mathrm{Cu}_{3}\left(\mathrm{PO}_{4}\right)_{2}$-based CaLB-HNFs and (b) $\mathrm{Mn}_{3}\left(\mathrm{PO}_{4}\right)_{2}$-based CaLB-HNFs.

To better assess the dissimilarities among the spectra of the CaLB-HNFs, we compared the correlation coefficients $(r)$ in the Amide I region (1600-1700 cm-1$)$, according to previously published work [43-45]. As seen from Table 1, for most of the CaLB-HNFs, $r$ was close to 1.0, indicating that CaLB was able to maintain its native secondary structure upon encapsulation in the nanoflower structure. GO has formed a cage-like structure in which lipase was encapsulated, preserving the secondary structure of the enzyme [27]. In contrast, when CaLB-HNFs were prepared with CNTs, especially when combined with GO, the changes in the $r$ value were more pronounced. This result could be attributed to conformational changes occurred during the encapsulation of CaLB in the nanoflower structure. The disorder of the natural conformation of CaLB, may arise from the over-crowded enzyme molecules within the strongly packed GO/CNTs HNF structure.

Table 1. Correlation coefficient $(r)$ between the FTIR spectra of CaLB-HNFs.

\begin{tabular}{cccc}
\hline Nanoflower & $\boldsymbol{r}$ & Nanoflower & $\boldsymbol{r}$ \\
\hline $\mathrm{Cu}_{3}\left(\mathrm{PO}_{4}\right)_{2}$ & 0.976 & $\mathrm{Mn}_{3}\left(\mathrm{PO}_{4}\right)_{2}$ & 0.982 \\
$\mathrm{GO}-\mathrm{Cu}_{3}\left(\mathrm{PO}_{4}\right)_{2}$ & 0.991 & $\mathrm{GO}-\mathrm{Mn}_{3}\left(\mathrm{PO}_{4}\right)_{2}$ & 0.998 \\
$\mathrm{CNTs}-\mathrm{Cu}_{3}\left(\mathrm{PO}_{4}\right)_{2}$ & 0.899 & $\mathrm{CNTs}-\mathrm{Mn}_{3}\left(\mathrm{PO}_{4}\right)_{2}$ & 0.837 \\
$\mathrm{GO} / \mathrm{CNTs}-\mathrm{Cu}_{3}\left(\mathrm{PO}_{4}\right)_{2}$ & 0.879 & $\mathrm{GO} / \mathrm{CNTs}-\mathrm{Mn}_{3}\left(\mathrm{PO}_{4}\right)_{2}$ & 0.801 \\
$\mathrm{GO} / \mathrm{Fe}_{2} \mathrm{O}_{3}-\mathrm{Cu}_{3}\left(\mathrm{PO}_{4}\right)_{2}$ & 0.991 & $\mathrm{GO} / \mathrm{Fe}_{2} \mathrm{O}_{3}-\mathrm{Mn}_{3}\left(\mathrm{PO}_{4}\right)_{2}$ & 0.998 \\
\hline
\end{tabular}

\subsection{Biocatalytic Characterization of CaLB Nanoflowers}

The encapsulation yield and specific hydrolytic activity of all CaLB-HNFs are presented in Table 2. The protein loading for unmodified $\mathrm{Cu}_{3}\left(\mathrm{PO}_{4}\right)_{2}$ and $\mathrm{Mn}_{3}\left(\mathrm{PO}_{4}\right)_{2} \mathrm{CaLB}-\mathrm{HNF}$ were 57.6\% and 49.0\%, respectively, while their specific activity was calculated at 8.3 and $96.7 \mathrm{U} \mathrm{g}^{-1}$, respectively, pointing out that the kind of the metal ion significantly affects the hydrolyzing ability of the immobilized lipase. It has been previously proposed that enzymes provide different binding sites for metal ions, and, as such, nucleation sites are formed in different enzyme regions, affecting the 3D structure and activity of the immobilized biocatalysts [15]. Moreover, in the case of $\mathrm{Cu}_{3}\left(\mathrm{PO}_{4}\right)_{2} \mathrm{CaLB}-\mathrm{HNFs}$, lipase could have been embedded deep inside the flower-like structure, preventing the active sites of the CaLB from interacting with the substrate and thus leading to low catalytic activity, due to steric hindrance phenomena $[28,46]$. 
Table 2. Encapsulation yield and specific hydrolytic activity of various CaLB-HNFs.

\begin{tabular}{ccc}
\hline Nanoflower & Encapsulation Yield (\%) & Specific Activity $\left(\mathbf{U ~ g ~}^{\mathbf{- 1}}\right.$ Immobilized CaLB) \\
\hline $\mathrm{Cu}_{3}\left(\mathrm{PO}_{4}\right)_{2}$ & $57.6 \pm 3.1$ & $13.1 \pm 0.5$ \\
$\mathrm{GO}-\mathrm{Cu}_{3}\left(\mathrm{PO}_{4}\right)_{2}$ & $70.5 \pm 1.7$ & $174.4 \pm 0.7$ \\
$\mathrm{CNTs}-\mathrm{Cu}_{3}\left(\mathrm{PO}_{4}\right)_{2}$ & $57.5 \pm 2.1$ & $189.0 \pm 3.9$ \\
$\mathrm{GO} / \mathrm{CNTs}-\mathrm{Cu}_{3}\left(\mathrm{PO}_{4}\right)_{2}$ & $61.6 \pm 1.5$ & $167.0 \pm 1.7$ \\
$\mathrm{GO} / \mathrm{Fe}_{2} \mathrm{O}_{3}-\mathrm{Cu}_{3}\left(\mathrm{PO}_{4}\right)_{2}$ & $59.0 \pm 2.4$ & $197.1 \pm 2.5$ \\
$\mathrm{Mn}_{3}\left(\mathrm{PO}_{4}\right)_{2}$ & $49.0 \pm 1.7$ & $161.2 \pm 2.6$ \\
$\mathrm{GO}-\mathrm{Mn}_{3}\left(\mathrm{PO}_{4}\right)_{2}$ & $67.1 \pm 3.6$ & $284.7 \pm 5.2$ \\
$\mathrm{CNTs}-\mathrm{Mn}_{3}\left(\mathrm{PO}_{4}\right)_{2}$ & $57.6 \pm 1.2$ & $175.6 \pm 4.0$ \\
$\mathrm{GO} / \mathrm{CNTs}-\mathrm{Mn}_{3}\left(\mathrm{PO}_{4}\right)_{2}$ & $65.9 \pm 2.5$ & $168.7 \pm 1.0$ \\
$\mathrm{GO} / \mathrm{Fe}_{2} \mathrm{O}_{3}-\mathrm{Mn}_{3}\left(\mathrm{PO}_{4}\right)_{2}$ & $60.9 \pm 2.7$ & $175.9 \pm 1.9$ \\
\hline
\end{tabular}

In order to provide more binding sites for the formation of CaLB-HNFs, different carbon-based and magnetic nanomaterials were added to the hybrid nanostructures during the preparation procedure. All HNFs enriched with carbon or magnetic nanomaterials exhibited higher encapsulation yields than those without nanomaterials, regardless of the metal ion type. The highest encapsulation yields were observed when GO was used as an additive. For instance, the encapsulation efficiency reached up to 70.5 and $67.1 \%$ in the case of GO-Cu ${ }_{3}\left(\mathrm{PO}_{4}\right)_{2}$ and GO-Mn $3\left(\mathrm{PO}_{4}\right)_{2}$ CaLB-NHFs, respectively. Similar results have also been reported by $\mathrm{Li}$ and co-workers when $\mathrm{GO}$ was added in the formation of laccase-based nanoflowers [27]. CNTs also seem to affect the immobilization efficiency of CaLB, as is consistent with previous work [28]. The large surface area of GO and CNTs seems to increase the available binding sites and thus promote enzyme adsorption, in addition to stabilizing the 3D structure of the nanoflower. Moreover, the presence of oxygen-containing groups in the surface of these nanomaterials may result in the formation of electrostatic interactions between those functional groups and the copper cations, stabilizing the nucleation step.

The modification of CaLB-HNFs with carbon or magnetic nanomaterials enhanced the specific hydrolytic activity of the immobilized enzyme. In the case of manganese-based nanoflowers, the specific activity of the enzyme was increased up to around two-times in the presence of nanomaterials. The beneficial effect of the use of nanomaterials was more pronounced in the case of copper-based nanoflowers. More specifically, all the nanomaterials significantly outperformed in terms of activity the unmodified $\mathrm{Cu}_{3}\left(\mathrm{PO}_{4}\right)_{2}$ nanoflowers. GO sheets, CNTs, and $\gamma-\mathrm{Fe}_{2} \mathrm{O}_{3}$ nanoparticles, due to randomly distributed oxygen-containing groups on their surface, interact with positively charged metals and amino groups on the enzyme's surface, leading to more stable and active flower-like structures [28]. Such interactions could lead to a more active conformation [47,48]. Compared to each individual nanomaterial, the GO/CNTs hybrid system was not as beneficial as expected, maybe due to the uniform dispersion of lipase within the nanoflower structure or stereochemical hindrance. Moreover, CaLB immobilized on GO/CNTs nanoflowers presented the highest conformational changes (as previously discussed, Table 1), which could result in lower catalytic activity. It is important to mention that the preparation of HNFs containing both carbon nanomaterials and magnetic nanoparticles has not been previously reported. $\mathrm{GO} / \mathrm{Fe}_{2} \mathrm{O}_{3}$-based $\mathrm{HNFs}$ reached high encapsulation yields, while $\mathrm{GO} / \mathrm{Fe}_{2} \mathrm{O}_{3}-\mathrm{Cu}_{3}\left(\mathrm{PO}_{4}\right)_{2} \mathrm{CaLB}-\mathrm{HNFs}$ exhibited one of the highest catalytic activities among all nanoflowers.

The thermal stability of the CaLB-HNFs was also investigated. The remaining hydrolytic activity was estimated after incubation of nanoflowers for up to $24 \mathrm{~h}$ in phosphate buffer at $60^{\circ} \mathrm{C}$, and is presented in Figure 4. 


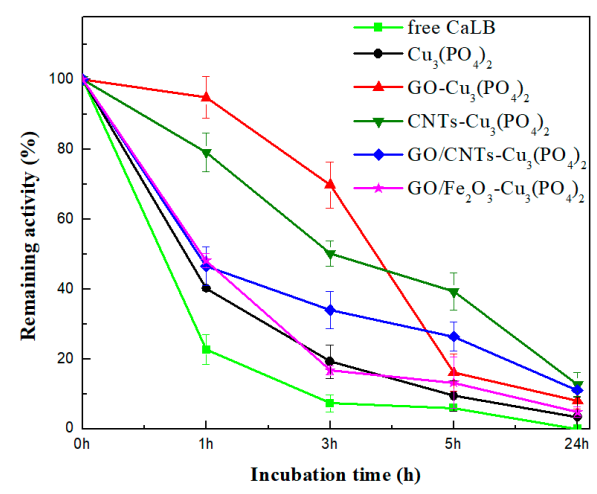

(a)

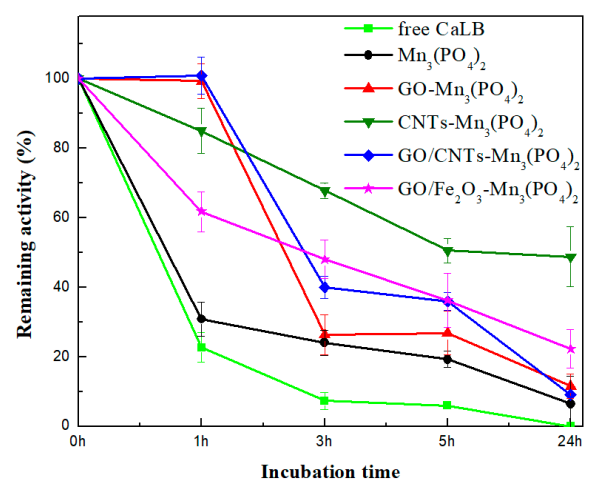

(b)

Figure 4. Thermal stability of: (a) $\mathrm{Cu}_{3}\left(\mathrm{PO}_{4}\right)_{2}$-based CaLB-HNFs and (b) $\mathrm{Mn}_{3}\left(\mathrm{PO}_{4}\right)_{2}$-based CaLB-HNFs at $60{ }^{\circ} \mathrm{C}$. The $100 \%$ percentage corresponds to the activity at $\mathrm{t}=0 \mathrm{~min}$.

As seen in Figure 4, the use of hybrid nanoflowers as supports for the immobilization of CaLB increased the thermal stability of the immobilized enzyme. Specifically, the catalytic activity of free CaLB decreased to $20 \%$ after the first hour of incubation, while unmodified $\mathrm{CaLB}-\mathrm{Cu}_{3}(\mathrm{PO} 4)_{2}$ and $\mathrm{Mn}_{3}\left(\mathrm{PO}_{4}\right)_{2}$ CaLB-HNFs retained up to $40 \%$ and $31 \%$ of their initial activity, respectively. Moreover, after $5 \mathrm{~h}$ of incubation, free CaLB was totally inactivated, while the immobilized lipase on unmodified HNFs retained up to $19.2 \%$ of their activity, indicating that the nanoflower 3D structure can protect the active conformation of the enzyme, thus enhancing its stability [49]. Similar observations have also been reported for lipase from the porcine pancreas [50]. The thermal stability of the immobilized CaLB was further improved when HNFs containing carbon and $\gamma-\mathrm{Fe}_{2} \mathrm{O}_{3}$ nanomaterials were used as immobilization supports. This observation could be attributed to the protective effect these nanomaterials offer on the stability of protein molecules [51,52]. Amongst the nanomaterials, CNTs stabilized the immobilized enzyme the most for both copper- and manganese-based nanoflowers ( $12.7 \%$ and $49 \%$ of enzyme activity, respectively, was retained after $24 \mathrm{~h}$ of incubation). Their high surface area, as well as the fact that CNTs are distributed within the petals of the flower-like structure, enables lipase to maintain its stability $[27,28]$. The conformational changes previously described (Table 1) may lead to a more rigid folding of lipase and thus enhance its stability [51]. Furthermore, in comparing the two inorganic components, it is clear that manganese HNFs exhibited higher remaining activity than copper HNFs, underlining the correlation of the different interactions developed between nanomaterials and each metal ion.

One of the major drawbacks of using soluble enzymes in large-scale reactions is reusability, due to their incapability of maintaining their stability under harsh conditions, and the difficulty of removal from the reaction system, due to their high solubility. Therefore, the immobilization of enzymes enhances their stability and enables their separation and use in successive cycles, making them an asset for industrial applications. In the present study, the operational stability of the CaLB-HNFs was investigated for the hydrolysis of $p$-NPB, and the results are presented in Figure 5. As seen, unmodified $\mathrm{Cu}_{3}\left(\mathrm{PO}_{4}\right)_{2}$ and $\mathrm{Mn}_{3}\left(\mathrm{PO}_{4}\right)_{2}$ CaLB-HNFs were almost deactivated after the fifth biocatalytic cycle. It is possible that the disruption of the non-covalent bonds between the organic and inorganic parts of the nanoflowers in the aqueous environment accelerated the enzyme leaching or gradual degradation of the flower-like morphology, leading to low enzymatic activity, which is in agreement with that recently reported [40].

In the case of nanomaterials-modified HNFs, the operational stability of CaLB was notably increased. Immobilized CaLB on nanomaterials-based HNFs could be efficiently used for nine consecutive cycles for the hydrolysis of $p$-NPB. The residual activity of nanomaterials-modified $\mathrm{Cu}_{3}(\mathrm{PO} 4)_{2}$ and $\mathrm{Mn}_{3}(\mathrm{PO} 4)_{2}$ CaLB-HNFs retained up to $83 \%$ even after nine catalytic cycles. These results infer that the presence of nanomaterials in the nanoflowers protects the enzyme configuration, 
thus enhancing its stability for successive hydrolysis cycles. Similar to the thermal stability studies presented above, CNTs-modified CaLB-HNFs offered the most beneficial impact on the operational stability of $\mathrm{CaLB}$, indicating that the incorporation of CNTs inside the nanoflower structure enables the adoption of a more rigid conformation of CaLB, stabilizing it against repeatable usage [53]. It is interesting to note that, although manganese-based HNFs presented higher thermal stability than copper-based HNFs (as previously discussed), their operational stability was lower compared to copper-based HNFs. It is possible that the enzyme leaching from the manganese-based HNFs is higher compared to copper-based HNFs, resulting in a higher loss of the residual activity of the enzyme.

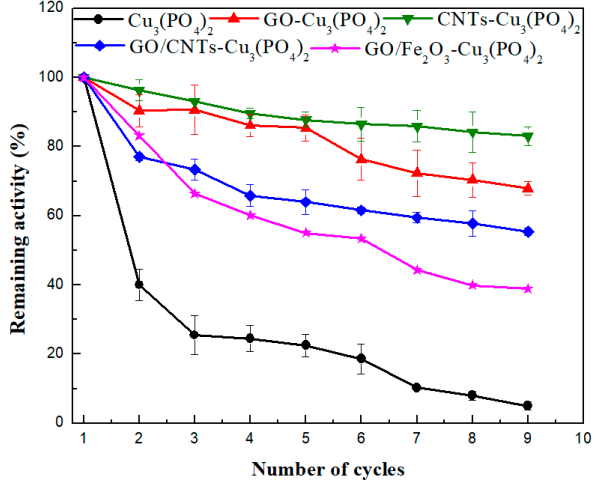

(a)

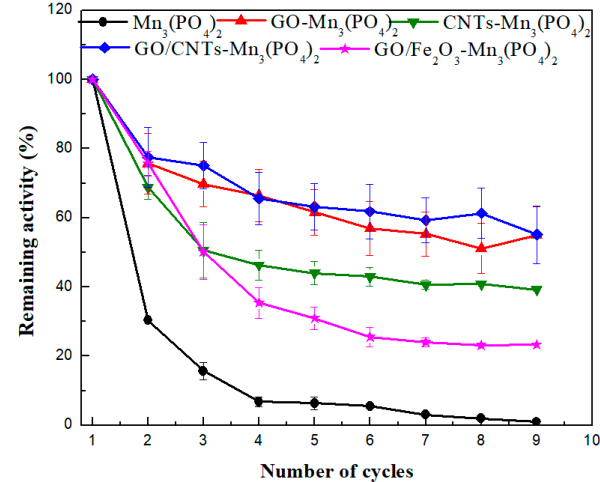

(b)

Figure 5. Operational stability of: (a) $\mathrm{Cu}_{3}\left(\mathrm{PO}_{4}\right)_{2}$-based CaLB-HNFs and (b) $\mathrm{Mn}_{3}\left(\mathrm{PO}_{4}\right)_{2}$-based CaLB-HNFs. The $100 \%$ percentage corresponds to the lipase hydrolytic activity at the first catalytic cycle.

\subsection{Transesterification of Tyrosol by CaLB Nanoflowers in Non-Aqueous Media}

The prepared nanomaterials-modified CaLB-HNFs were used for the synthesis of tyrosol esters in non-aqueous media. Tyrosol is a natural phenolic antioxidant derived from various plants, such as olive and green tea. This abundant product has been associated with many health-related benefits as well as plenty of industrial applications [54,55]. An increase of tyrosol lipophilicity is suggested to improve its antioxidant activity [56,57]. Thus, the enzymatic lipophilization of tyrosol may be of great interest. For this reason, $\mathrm{GO} / \mathrm{Fe}_{2} \mathrm{O}_{3}-\mathrm{Cu}_{3}\left(\mathrm{PO}_{4}\right)_{2}$ and $\mathrm{GO} / \mathrm{Fe}_{2} \mathrm{O}_{3}-\mathrm{Mn}_{3}\left(\mathrm{PO}_{4}\right)_{2} \mathrm{CaLB}-\mathrm{HNF}$ were used as biocatalysts for the transesterification of tyrosol with vinyl butyrate (Figure S4) in a variety of organic solvents, as well as in environmentally friendly ionic and deep eutectic solvents; the results are presented in Table 3. GO/CNTs-based HNFs were also used for the transesterification of tyrosol; the results are presented in Table $\mathrm{S} 2$.

Table 3. Conversion yields for the enzymatic transesterification of tyrosol with vinyl butyrate in non-aqueous media catalyzed by $\mathrm{GO} / \mathrm{Fe}_{2} \mathrm{O}_{3}-\mathrm{Cu}_{3}\left(\mathrm{PO}_{4}\right)_{2}$ and $\mathrm{GO} / \mathrm{Fe}_{2} \mathrm{O}_{3}-\mathrm{Mn}_{3}\left(\mathrm{PO}_{4}\right)_{2} \mathrm{CaLB} \mathrm{HNFs}$.

\begin{tabular}{|c|c|c|}
\hline \multirow{2}{*}{ Reaction Medium } & \multicolumn{2}{|c|}{ Conversion Yield (\%) } \\
\hline & $\mathrm{GO} / \mathrm{Fe}_{2} \mathrm{O}_{3}-\mathrm{Cu}_{3}\left(\mathrm{PO}_{4}\right)_{2} \mathrm{CaLB}-\mathrm{HNFs}$ & $\mathrm{GO} / \mathrm{Fe}_{2} \mathrm{O}_{3}-\mathrm{Mn}_{3}\left(\mathrm{PO}_{4}\right)_{2} \mathrm{CaLB}-\mathrm{HNFs}$ \\
\hline n-Hexane & $99.6 \pm 0.4$ & $100.0 \pm 0.3$ \\
\hline Acetonitrile & $80.3 \pm 0.3$ & $80.7 \pm 0.8$ \\
\hline 2-Methyl-2-butanol & $30.2 \pm 1.1$ & $52.6 \pm 1.2$ \\
\hline tert-Butyl-methylether & $98.9 \pm 0.5$ & $99.7 \pm 0.6$ \\
\hline tert-Butanol & $23.2 \pm 0.2$ & $22.5 \pm 0.4$ \\
\hline$[\mathrm{BMIM}]\left[\mathrm{PF}_{6}\right]$ & $13.6 \pm 1.6$ & $20.0 \pm 4.7$ \\
\hline ChCl:U & $33.2 \pm 2.8$ & $26.7 \pm 4.6$ \\
\hline
\end{tabular}


As seen in Table 3, both CaLB-HNFs were able to catalyze the transesterification of tyrosol, achieving high conversion yields in most of the non-aqueous solvents. It has been recently proposed that the hydrophobic surface of the hybrid nanoflowers benefits synthetic reactions in non-aqueous solvents by promoting the oriented delivery of the substrates near the hydrophobic surface of nanoflowers and, thus, to the active sites of the enzyme [49]. Conversion yields of transesterification seem to strongly depend on the nature of the organic solvent, namely its polarity and viscosity. More specifically, the nanoflower-catalyzed reactions in non-polar solvents, e.g., n-hexane and tert-butyl-methylether, exhibited high conversion yields up to $100 \%$. Moreover, the reaction rate of the transesterification reaction catalyzed by $\mathrm{GO} / \mathrm{Fe}_{2} \mathrm{O}_{3}-\mathrm{Mn}_{3}\left(\mathrm{PO}_{4}\right)_{2} \mathrm{CaLB}-\mathrm{HNFs}$ in hexane and tert-butyl-methylether was up to 73-fold higher in comparison with that in other media (Table S3). Solvents with low polarity enable enzymes to preserve the essential water molecules bound on their surface in order to maintain their natural conformation and be fully functional [58,59]. On the other hand, the use of more hydrophilic solvents with higher affinity to interact with water molecules [60], such as 2-methyl-2-butanol and tert-butanol, led to a decrease of the conversion yield of the transesterification reaction.

Both HNFs were able to catalyze the transesterification of tyrosol in eco-friendly alternatives

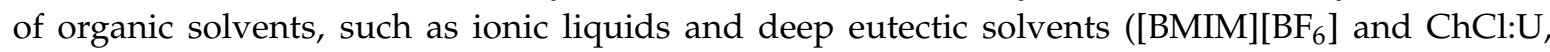
respectively). Those green solvents have been widely employed for enzymatic biotransformations, as they present high chemical and thermal stability, low vapour pressure, low toxicity, and the ability to enhance the catalytic performance of the enzymes [17,55,61]. As seen in Table 3, the conversion yield is decreased in the ionic liquid compared to organic solvents, which could be attributed to the low dispersability of the nanoflowers in these media. Moreover, the high viscosity of $[\mathrm{BMIM}]\left[\mathrm{BF}_{6}\right](381 \mathrm{cP}$ at $\left.25^{\circ} \mathrm{C}\right)$ [62] and $\mathrm{ChCl:U}\left(1200 \mathrm{mPa}\right.$ s at $\left.25^{\circ} \mathrm{C}\right)$ [63] could lead to mass-transfer limitations, restricting the biocatalytic activity of immobilized CaLB $[64,65]$.

The use of magnetic nanobiocatalysts could facilitate the separation from the reaction solution through the application of an external magnetic field and, thus, the reuse of the biocatalyst [52]. Considering this aspect, magnetic CaLB-HNFs were applied in consecutive reaction cycles for tyrosol transesterification. Figure 6 presents the remaining catalytic activity of the $\mathrm{GO} / \mathrm{Fe}_{2} \mathrm{O}_{3}-\mathrm{Mn}_{3}\left(\mathrm{PO}_{4}\right)_{2}$ CaLB-HNFs for successive catalytic cycles. As seen, these magnetic nanoflowers presented excellent operational stability after eight consecutive reaction cycles ( $576 \mathrm{~h}$ of total operation) without any loss of biocatalytic activity, making this hybrid nanobiocatalyst one of the most robust nanobiocatalysts reported until now for similar reaction processes. This enhanced operational stability, in comparison with the one described above for the hydrolysis of $p$-NPB (Figure 5), could be attributed to the fact that non-polar organic solvents do not remove protein-bound water that is crucial for maintaining protein structure and function, leading to a more rigid conformation of the immobilized biocatalyst $[66,67]$.

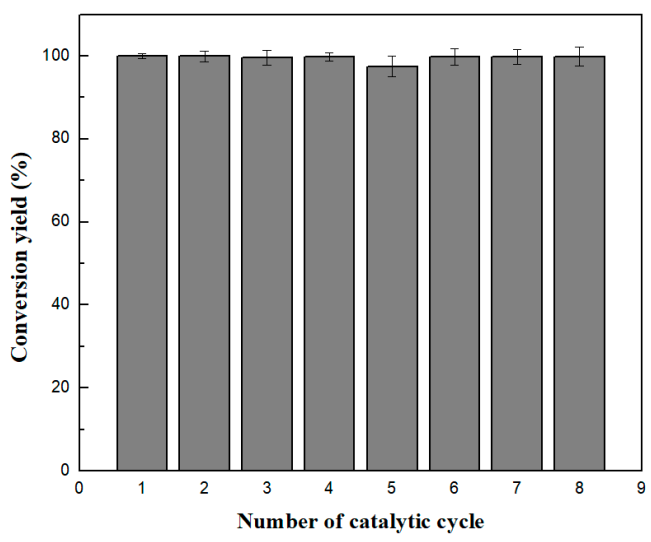

Figure 6. Operational stability of $\mathrm{GO} / \mathrm{Fe}_{2} \mathrm{O}_{3}-\mathrm{Mn}_{3}\left(\mathrm{PO}_{4}\right)_{2} \mathrm{CaLB}-\mathrm{HNF}$ after eight reaction cycles for the enzymatic transesterification of tyrosol with vinyl butyrate in tert-butyl-methylether. Each reaction was carried out for $72 \mathrm{~h}$ at $50{ }^{\circ} \mathrm{C}$. 


\section{Conclusions}

Herein, we report the preparation and characterization of novel hybrid nanoflowers comprised of copper (II) or manganese (II) ions combined with magnetic nanoparticles and carbon-based nanomaterials. These nanoflowers can be effectively used as versatile host platforms for the immobilization of an industrially relevant enzyme (CaLB) through biomimetic mineralization. The metal ion and the nature of the nanomaterials affect the structural and catalytic characteristics of the immobilized lipase in different manners. The nanomaterials-modified hybrid nanoflowers presented an excellent catalytic performance in the production of tyrosol esters in different organic solvents and environmental-friendly ionic solvents. Furthermore, CaLB-magnetic HNFs (combining GO and maghemite nanoparticles) exhibited remarkable operational stability for the tyrosol transesterification reaction, as the nanobiocatalyst retained almost its entire catalytic activity even after eight successive reaction cycles, indicating that these bio-nanoconjugates could potentially be used as efficient tools for heterogeneous biocatalytic transformations in large-scale applications.

Supplementary Materials: The following are available online at http://www.mdpi.com/2079-4991/9/6/808/s1, Figure S1: SEM images of: (A1, A2) $\mathrm{Cu}_{3}\left(\mathrm{PO}_{4}\right)_{2} \mathrm{CaLB}-\mathrm{HNFs}$; (B1-B3) GO-Cu$\left(\mathrm{PO}_{4}\right)_{2} \mathrm{CaLB}-\mathrm{HNFs}$; (C1-C3) CNTs-Cu $3\left(\mathrm{PO}_{4}\right)_{2}$ CaLB-HNFs; (D1-D3) GO/CNTs-Cu $\left(\mathrm{PO}_{4}\right)_{2}$ CaLB-HNFs; (E1, E2) GO/Fe $\mathrm{O}_{3}-\mathrm{Cu}_{3}\left(\mathrm{PO}_{4}\right)_{2}$ CaLB-HNFs; (F1-F3) $\mathrm{Mn}_{3}\left(\mathrm{PO}_{4}\right)_{2}$ CaLB-HNFs; (G1-G3) GO-Mn $3\left(\mathrm{PO}_{4}\right)_{2}$ CaLB-HNFs; $(\mathrm{H} 1, \mathrm{H} 2)$ CNTs-Mn $3\left(\mathrm{PO}_{4}\right)_{2}$ CaLB-HNFs; (I1-I3) GO/CNTs-Mn ${ }_{3}\left(\mathrm{PO}_{4}\right)_{2}$ CaLB-HNFs; (J1, J2) GO/Fe $\mathrm{O}_{3}-\mathrm{Mn}_{3}\left(\mathrm{PO}_{4}\right)_{2}$ CaLB-HNFs, Figure S2: EDS spectra of: (a) GO/Fe $\mathrm{O}_{3}-\mathrm{Cu}_{3}\left(\mathrm{PO}_{4}\right)_{2} \mathrm{CaLB}-\mathrm{HNF}$; (b) $\mathrm{GO} / \mathrm{Fe}_{2} \mathrm{O}_{3}-\mathrm{Mn}_{3}\left(\mathrm{PO}_{4}\right)_{2}$ CaLB-HNFs, Table S1: Elemental analysis of $\mathrm{GO} / \mathrm{Fe}_{2} \mathrm{O}_{3}$-based CaLB-HNFs by EDS, Figure S3: XRD patterns of: (a) $\mathrm{Cu}_{3}\left(\mathrm{PO}_{4}\right)_{2}$-based CaLB-HNFs; (b) $\mathrm{Mn}_{3}\left(\mathrm{PO}_{4}\right)_{2}$-CaLB-HNFs, Figure S4: Transesterification of tyrosol with vinyl butyrate catalyzed by CaLB, Table S2: Conversion yields for the enzymatic transesterification of tyrosol with vinyl butyrate in non aqueous media, by GO/CNTs-Cu $\mathrm{Cu}_{3}\left(\mathrm{PO}_{2}\right.$ CaLB-HNFs, Table S3: Reaction rates $\left(\mathrm{mM} \mathrm{h}^{-1}\right)$ of tyrosol transesterification catalyzed by $\mathrm{GO} / \mathrm{Fe}_{2} \mathrm{O}_{3}-\mathrm{Mn}_{3}\left(\mathrm{PO}_{4}\right)_{2} \mathrm{CaLB}-\mathrm{HNFs}$ in non-aqueous media.

Author Contributions: H.S. contributed to the overall design of the experiments, results interpretation, and manuscript writing. D.G., A.A., A.P., and E.P.G. contributed to results interpretation and reviewed the manuscript. R.F. performed the synthesis and experiments with nanoflowers, results interpretation, and manuscript writing. M.P. contributed to results interpretation and manuscript writing. M.A.H., A.E., K.S., and D.M. performed the synthesis of nanomaterials. S.E.M., E.D.S., and X.R.D. contributed to the characterization of nanoflowers and the results analysis. K.T. performed the Raman characterization of nanoflowers, contributed to results analysis, and reviewed the manuscript.

Funding: This research has been co-financed by the European Regional Development Fund of the European Union and Greek national funds through the Operational Program Competitiveness, Entrepreneurship and Innovation, under the call RESEARCH-CREATE-INNOVATE (project code: T1EDK- 01716).

Acknowledgments: This work made use of the Cornell Center for Materials Research Shared Facilities which are supported through the NSF MRSEC program (DMR-1719875).

Conflicts of Interest: The authors declare no conflict of interest.

\section{References}

1. Ansari, S.A.; Husain, Q. Potential applications of enzymes immobilized on/in nano materials: A review. Biotechnol. Adv. 2012, 30, 512-523. [CrossRef] [PubMed]

2. Cipolatti, E.P.; Valério, A.; Henriques, R.O.; Moritz, D.E.; Ninow, J.L.; Freire, D.M.G.; Manoel, E.A.; Fernandez-Lafuente, R.; De Oliveira, D. Nanomaterials for biocatalyst immobilization - state of the art and future trends. RSC Adv. 2016, 6, 104675-104692. [CrossRef]

3. Di Credico, B.; Redaelli, M.; Bellardita, M.; Calamante, M.; Cepek, C.; Cobani, E.; D'Arienzo, M.; Evangelisti, C.; Marelli, M.; Moret, M.; et al. Step-by-Step Growth of HKUST-1 on Functionalized $\mathrm{TiO}_{2}$ Surface: An Efficient Material for $\mathrm{CO}_{2}$ Capture and Solar Photoreduction. Catalysts 2018, 8, 353. [CrossRef]

4. Di Credico, B.; Cobani, E.; Callone, E.; Conzatti, L.; Cristofori, D.; D'Arienzo, M.; Dirè, S.; Giannini, L.; Hanel, T.; Scotti, R.; et al. Size-controlled self-assembly of anisotropic sepiolite fibers in rubber nanocomposites. Appl. Clay Sci. 2018, 152, 51-64. [CrossRef]

5. Pavlidis, I.V.; Patila, M.; Bornscheuer, U.T.; Gournis, D.; Stamatis, H. Graphene-based nanobiocatalytic systems: recent advances and future prospects. Trends Biotechnol. 2014, 32, 312-320. [CrossRef] [PubMed] 
6. Shende, P.; Kasture, P.; Gaud, R. Nanoflowers: the future trend of nanotechnology for multi-applications. Artif. Cells Nanomed. Biotechnol. 2018, 46, 413-422. [CrossRef]

7. Cui, J.; Jia, S. Organic-inorganic hybrid nanoflowers: A novel host platform for immobilizing biomolecules. Co-ord. Chem. Rev. 2017, 352, 249-263. [CrossRef]

8. Ge, J.; Lei, J.; Zare, R.N. Protein-inorganic hybrid nanoflowers. Nat. Nanotechnol. 2012, 7, 428-432. [CrossRef]

9. Batule, B.S.; Park, K.S.; Gautam, S.; Cheon, H.J.; Kim, M.I.; Park, H.G. Intrinsic peroxidase-like activity of sonochemically synthesized protein copper nanoflowers and its application for the sensitive detection of glucose. Sens. Actuators B Chem. 2018, 283, 749-754. [CrossRef]

10. Chen, X.; Xu, L.; Wang, A.; Li, H.; Wang, C.; Pei, X.; Zhang, P.; Wu, S.G. Efficient synthesis of the key chiral alcohol intermediate of Crizotinib using dual-enzyme@CaHPO4 hybrid nanoflowers assembled by mimetic biomineralization. J. Chem. Technol. Biotechnol. 2019, 94, 236-243. [CrossRef]

11. Altinkaynak, C.; Tavlasoglu, S.; Kalin, R.; Sadeghian, N.; Ozdemir, H.; Ocsoy, I.; Özdemir, N. A hierarchical assembly of flower-like hybrid Turkish black radish peroxidase- $\mathrm{Cu}^{2+}$ nanobiocatalyst and its effective use in dye decolorization. Chemosphere 2017, 182, 122-128. [CrossRef]

12. Li, P.; Zhang, B.; Fan, L.; Wang, H.; Tian, L.; Ali, N. Papain/ $/ \mathrm{Zn}_{3}\left(\mathrm{PO}_{4}\right)_{2}$ hybrid nanoflower: preparation, characterization and its enhanced catalytic activity as an immobilized enzyme. RSC Adv. 2016, 6, 46702-46710.

13. López-Gallego, F.; Yate, L. Selective biomineralization of $\mathrm{Co}_{3}\left(\mathrm{PO}_{4}\right)_{2}$-sponges triggered by His-tagged proteins: efficient heterogeneous biocatalysts for redox processes. Chem. Commun. 2015, 51, 8753-8756. [CrossRef] [PubMed]

14. Ocsoy, I.; Dogru, E.; Usta, S. A new generation of flowerlike horseradish peroxides as a nanobiocatalyst for superior enzymatic activity. Enzym. Microb. Technol. 2015, 75, 25-29. [CrossRef]

15. Escobar, S.; Velasco-Lozano, S.; Lu, C.-H.; Lin, Y.-F.; Mesa, M.; Bernal, C.; López-Gallego, F. Understanding the functional properties of bio-inorganic nanoflowers as biocatalysts by deciphering the metal-binding sites of enzymes. J. Mater. Chem. B 2017, 5, 4478-4486. [CrossRef]

16. Patel, S.K.; Otari, S.V.; Li, J.; Kim, D.R.; Kim, S.C.; Cho, B.-K.; Kalia, V.C.; Kang, Y.C.; Lee, J.-K. Synthesis of cross-linked protein-metal hybrid nanoflowers and its application in repeated batch decolorization of synthetic dyes. J. Hazard. Mater. 2018, 347, 442-450. [CrossRef] [PubMed]

17. Papadopoulou, A.A.; Tzani, A.; Polydera, A.C.; Katapodis, P.; Voutsas, E.; Detsi, A.; Stamatis, H. Green biotransformations catalysed by enzyme-inorganic hybrid nanoflowers in environmentally friendly ionic solvents. Environ. Sci. Pollut. Res. 2018, 25, 26707-26714. [CrossRef]

18. Zhu, L.; Gong, L.; Zhang, Y.; Wang, R.; Ge, J.; Liu, Z.; Zare, R.N. Rapid Detection of Phenol Using a Membrane Containing Laccase Nanoflowers. Chem. Asian J. 2013, 8, 2358-2360. [CrossRef] [PubMed]

19. Fu, M.; Xing, J.; Ge, Z. Preparation of laccase-loaded magnetic nanoflowers and their recycling for efficient degradation of bisphenol A. Sci. Total Environ. 2019, 651, 2857-2865. [CrossRef] [PubMed]

20. Bao, J.; Huang, T.; Wang, Z.; Yang, H.; Geng, X.; Xu, G.; Samalo, M.; Sakinati, M.; Huo, D.; Hou, C. 3D graphene/copper oxide nano-flowers based acetylcholinesterase biosensor for sensitive detection of organophosphate pesticides. Sens. Actuators B Chem. 2019, 279, 95-101. [CrossRef]

21. Zhu, X.; Huang, J.; Liu, J.; Zhang, H.; Jiang, J.; Yu, R. A dual enzyme-inorganic hybrid nanoflower incorporated microfluidic paper-based analytic device ( $\mu$ PAD) biosensor for sensitive visualized detection of glucose. Nanoscale 2017, 9, 5658-5663. [CrossRef]

22. Sharma, N.; Parhizkar, M.; Cong, W.; Mateti, S.; Kirkland, M.A.; Puri, M.; Sutti, A. Metal ion type significantly affects the morphology but not the activity of lipase-metal-phosphate nanoflowers. RSC Adv. 2017, 7, 25437-25443. [CrossRef]

23. Zeng, J.; Xia, Y. Not just a pretty flower. Nat. Nanotechnol. 2012, 7, 415-416. [CrossRef] [PubMed]

24. Lin, Z.; Xiao, Y.; Wang, L.; Yin, Y.; Zheng, J.; Yang, H.; Chen, G. Facile synthesis of enzyme-inorganic hybrid nanoflowers and their application as an immobilized trypsin reactor for highly efficient protein digestion. RSC Adv. 2014, 4, 13888-13891. [CrossRef]

25. Cui, J.; Zhao, Y.; Liu, R.; Zhong, C.; Jia, S. Surfactant-activated lipase hybrid nanoflowers with enhanced enzymatic performance. Sci. Rep. 2016, 6, 27928. [CrossRef]

26. Wang, X.; Shi, J.; Li, Z.; Zhang, S.; Wu, H.; Jiang, Z.; Yang, C.; Tian, C. Facile One-Pot Preparation of Chitosan/Calcium Pyrophosphate Hybrid Microflowers. ACS Appl. Mater. Interfaces 2014, 6, 14522-14532. [CrossRef] 
27. Li, H.; Hou, J.; Duan, L.; Ji, C.; Zhang, Y.; Chen, V. Graphene oxide-enzyme hybrid nanoflowers for efficient water soluble dye removal. J. Hazard. Mater. 2017, 338, 93-101. [CrossRef] [PubMed]

28. Li, K.; Wang, J.; He, Y.; Abdulrazaq, M.A.; Yan, Y. Carbon nanotube-lipase hybrid nanoflowers with enhanced enzyme activity and enantioselectivity. J. Biotechnol. 2018, 281, 87-98. [CrossRef]

29. Stergiou, D.V.; Diamanti, E.K.; Gournis, D.; Prodromidis, M.I.; Prodromidis, M. (Mamas) Comparative study of different types of graphenes as electrocatalysts for ascorbic acid. Electrochem. Commun. 2010, 12, 1307-1309. [CrossRef]

30. Tsoufis, T.; Tomou, A.; Gournis, D.; Douvalis, A.P.; Panagiotopoulos, I.; Kooi, B.; Georgakilas, V.; Arfaoui, I.; Bakas, T. Novel Nanohybrids Derived from the Attachment of FePt Nanoparticles on Carbon Nanotubes. J. Nanosci. Nanotechnol. 2008, 8, 5942-5951. [CrossRef]

31. Tzitzios, V.K.; Bakandritsos, A.; Georgakilas, V.; Basina, G.; Boukos, N.; Bourlinos, A.B.; Niarchos, D.; Petridis, D. Large-Scale Synthesis, Size Control, and Anisotropic Growth of \&gamma-Fe2O3 Nanoparticles: Organosols and Hydrosols. J. Nanosci. Nanotechnol. 2007, 7, 2753-2757. [PubMed]

32. Prestrelski, S.; Tedeschi, N.; Arakawa, T.; Carpenter, J. Dehydration-induced conformational transitions in proteins and their inhibition by stabilizers. Biophys. J. 1993, 65, 661-671. [CrossRef]

33. Bradford, M.M. A rapid and sensitive method for the quantitation of microgram quantities of protein utilizing the principle of protein-dye binding. Anal. Biochem. 1976, 72, 248-254. [CrossRef]

34. Huang, Y.; Fang, J.; Omenya, F.; O'Shea, M.; Chernova, N.A.; Zhang, R.; Wang, Q.; Quackenbush, N.F.; Piper, L.F.J.; Scanlon, D.; et al. Understanding the stability of $\mathrm{MnPO}_{4}$. J. Mater. Chem. A 2014, 2, 12827. [CrossRef]

35. Kharbish, S.; Andráš, P.; Luptáková, J.; Milovská, S. Raman spectra of oriented and non-oriented Cu hydroxy-phosphate minerals: Libethenite, cornetite, pseudomalachite, reichenbachite and ludjibaite. Spectrochim. Acta - Part A Mol. Biomol. Spectrosc. 2014, 130, 152-163. [CrossRef] [PubMed]

36. Sahana, M.B.; Vasu, S.; Sasikala, N.; Anandan, S.; Sepehri-Amin, H.; Sudakar, C.; Gopalan, R. Raman spectral signature of Mn-rich nanoscale phase segregations in carbon free LiFe1-xMnxPO4 prepared by hydrothermal technique. RSC Adv. 2014, 4, 64429-64437. [CrossRef]

37. Tsirka, K.; Katsiki, A.; Chalmpes, N.; Gournis, D.; Paipetis, A.S. Mapping of Graphene Oxide and Single Layer Graphene Flakes-Defects Annealing and Healing. Front. Mater. 2018, 5, 1-11. [CrossRef]

38. Kaniyoor, A.; Ramaprabhu, S. A Raman spectroscopic investigation of graphite oxide derived graphene. AIP Adv. 2012, 2, 32183. [CrossRef]

39. Rong, J.; Zhang, T.; Qiu, F.; Zhu, Y. Preparation of Efficient, Stable, and Reusable Laccase- $\mathrm{Cu}_{3}\left(\mathrm{PO}_{4}\right)_{2} \mathrm{Hybrid}$ Microspheres Based on Copper Foil for Decoloration of Congo Red. ACS Sustain. Chem. Eng. 2017, 5, 4468-4477. [CrossRef]

40. Lee, H.R.; Chung, M.; Kim, M.I.; Ha, S.H. Preparation of glutaraldehyde-treated lipase-inorganic hybrid nanoflowers and their catalytic performance as immobilized enzymes. Enzym. Microb. Technol. 2017, 105, 24-29. [CrossRef]

41. Chatzikonstantinou, A.V.; Gkantzou, E.; Gournis, D.; Patila, M.; Stamatis, H. Stabilization of Laccase Through Immobilization on Functionalized GO-Derivatives. In Enzyme Nanoarchitectures: Enzymes Armored with Graphene, 1st ed.; Kumar, C.V., Ed.; Elsevier Inc.: Amsterdam, The Netherlands, 2018; Volume 609, pp. 47-81. ISBN 9780128152409.

42. Patila, M.; Diamanti, E.K.; Bergouni, D.; Polydera, A.C.; Gournis, D.; Stamatis, H. Preparation and biochemical characterisation of nanoconjugates of functionalized carbon nanotubes and cytochrome c. Nanomed. Res. J. 2018, 3, 10-18.

43. Tzialla, A.A.; Pavlidis, I.V.; Felicissimo, M.P.; Rudolf, P.; Gournis, D.; Stamatis, H. Lipase immobilization on smectite nanoclays: Characterization and application to the epoxidation of $\alpha$-pinene. Bioresour. Technol. 2010, 101, 1587-1594. [CrossRef] [PubMed]

44. Secundo, F.; Carrea, G. Mono- and disaccharides enhance the activity and enantioselectivity ofBurkholderia cepacia lipase in organic solvent but do not significantly affect its conformation. Biotechnol. Bioeng. 2005, 92, 438-446. [CrossRef] [PubMed]

45. Secundo, F.; Barletta, G.L.; Dumitriu, E. Carre Can an Inactivating Agent Increase Enzyme Activity in Organic Solvent? Effects of 18-Crown-6 on Lipase Activity, Enantioselectivity, and Conformation. Biotechnol. Bioeng. 2007, 97, 12-18. [CrossRef] [PubMed] 
46. Hao, M.; Fan, G.; Zhang, Y.; Xin, Y.; Zhang, L. Preparation and characterization of copper-Brevibacterium cholesterol oxidase hybrid nanoflowers. Int. J. Boil. Macromol. 2019, 126, 539-548. [CrossRef] [PubMed]

47. Zhang, H.; Fei, X.; Tian, J.; Li, Y.; Zhi, H.; Wang, K.; Xu, L.; Wang, Y. Synthesis and continuous catalytic application of alkaline protease nanoflowers-PVA composite hydrogel. Catal. Commun. 2018, 116, 5-9. [CrossRef]

48. Garcia-Galan, C.; Berenguer-Murcia, Á.; Fernandez-Lafuente, R.; Rodrigues, R.C. Potential of Different Enzyme Immobilization Strategies to Improve Enzyme Performance. Adv. Synth. Catal. 2011, 353, 2885-2904. [CrossRef]

49. Gao, J.; Kong, W.; Zhou, L.; He, Y.; Ma, L.; Wang, Y.; Yin, L.; Jiang, Y. Monodisperse core-shell magnetic organosilica nanoflowers with radial wrinkle for lipase immobilization. Chem. Eng. J. 2017, 309, 70-79. [CrossRef]

50. Jiang, W.; Wang, X.; Yang, J.; Han, H.; Li, Q.; Tang, J. Lipase-inorganic hybrid nanoflower constructed through biomimetic mineralization: A new support for biodiesel synthesis. J. Colloid Interface Sci. 2018, 514, 102-107. [CrossRef]

51. Patila, M.; Pavlidis, I.V.; Kouloumpis, A.; Dimos, K.; Spyrou, K.; Katapodis, P.; Gournis, D.; Stamatis, H. Graphene oxide derivatives with variable alkyl chain length and terminal functional groups as supports for stabilization of cytochrome c. Int. J. Boil. Macromol. 2016, 84, 227-235. [CrossRef]

52. Orfanakis, G.; Patila, M.; Catzikonstantinou, A.V.; Lyra, K.-M.; Kouloumpis, A.; Spyrou, K.; Katapodis, P.; Paipetis, A.; Rudolf, P.; Gournis, D.; et al. Hybrid Nanomaterials of Magnetic Iron Nanoparticles and Graphene Oxide as Matrices for the Immobilization of $\beta$-Glucosidase: Synthesis, Characterization, and Biocatalytic Properties. Front. Mater. 2018, 5, 1-11. [CrossRef]

53. Bilal, M.; Asgher, M.; Iqbal, M.; Hu, H.; Zhang, X. Chitosan beads immobilized manganese peroxidase catalytic potential for detoxification and decolorization of textile effluent. Int. J. Boil. Macromol. 2016, 89, 181-189. [CrossRef] [PubMed]

54. Rodríguez-Morató, J.; Boronat, A.; Kotronoulas, A.; Pujadas, M.; Pastor, A.; Olesti, E.; Pérez-Mañá, C.; Khymenets, O.; Fitó, M.; Farré, M.; et al. Metabolic disposition and biological significance of simple phenols of dietary origin: hydroxytyrosol and tyrosol. Drug Metab. Rev. 2016, 48, 1-19. [CrossRef]

55. Papadopoulou, A.A.; Katsoura, M.H.; Chatzikonstantinou, A.; Kyriakou, E.; Polydera, A.C.; Tzakos, A.G.; Stamatis, H. Enzymatic hybridization of $\alpha$-lipoic acid with bioactive compounds in ionic solvents. Bioresour. Technol. 2013, 136, 41-48. [CrossRef]

56. Aissa, I.; Sghair, R.M.; Bouaziz, M.; Laouini, D.; Sayadi, S.; Gargouri, Y. Synthesis of lipophilic tyrosyl esters derivatives and assessment of their antimicrobial and antileishmania activities. Lipids Heal. 2012, 11, 13. [CrossRef]

57. Zhou, D.-Y.; Sun, Y.-X.; Shahidi, F. Preparation and antioxidant activity of tyrosol and hydroxytyrosol esters. J. Funct. Foods 2017, 37, 66-73. [CrossRef]

58. Zaks, A.; Klibanov, A.M. The effect of water on enzyme action in organic media. J. Boil. Chem. 1988, 263, 8017-8021.

59. Klibanov, A.M.; Klibanov, A.M.; Klibanov, A.M. Improving enzymes by using them in organic solvents. Nat. Cell Boil. 2001, 409, 241-246. [CrossRef] [PubMed]

60. Sharma, S.; Kanwar, S.S. Organic Solvent Tolerant Lipases and Applications. Sci. World J. 2014, 2014, 1-15.

61. Sheldon, R.A. Biocatalysis and Biomass Conversion in Alternative Reaction Media. Chem. A Eur. J. 2016, 22, 12984-12999. [CrossRef]

62. Dyson, P.J.; Laurenczy, G. Determination of the Viscosity of the Ionic Liquids [bmim][PF6] and [bmim][TF2N] Under High CO2 Gas Pressure Using Sapphire NMR Tubes. Zeitschrift für Naturforschung B 2008, 63, 681-684. [CrossRef]

63. Stefanovic, R.; Ludwig, M.; Webber, G.B.; Atkin, R.; Page, A.J. Nanostructure, Hydrogen Bonding and Rheology in Choline Chloride Deep Eutectic Solvents as a Function of the Hydrogen Bond Donor. Phys. Chem. Chem. Phys. 2017, 19, 3297-3306. [CrossRef] [PubMed]

64. Qin, J.; Zou, X.; Lv, S.; Jin, Q.; Wang, X. Influence of ionic liquids on lipase activity and stability in alcoholysis reactions. RSC Adv. 2016, 6, 87703-87709. [CrossRef]

65. Zeuner, B.; Ståhlberg, T.; Van Buu, O.N.; Kunov-Kruse, A.J.; Riisager, A.; Meyer, A.S. Dependency of the hydrogen bonding capacity of the solvent anion on the thermal stability of feruloyl esterases in ionic liquid systems. Green Chem. 2011, 13, 1550-1557. [CrossRef] 
66. Wang, S.; Meng, X.; Zhou, H.; Liu, Y.; Secundo, F.; Liu, Y. Enzyme Stability and Activity in Non-Aqueous Reaction Systems: A Mini Review. Catalysts 2016, 6, 32. [CrossRef]

67. Stepankova, V.; Bidmanova, S.; Koudelakova, T.; Prokop, Z.; Chaloupkova, R.; Damborsky, J. Strategies for Stabilization of Enzymes in Organic Solvents. ACS Catal. 2013, 3, 2823-2836. [CrossRef]

(C) 2019 by the authors. Licensee MDPI, Basel, Switzerland. This article is an open access article distributed under the terms and conditions of the Creative Commons Attribution (CC BY) license (http://creativecommons.org/licenses/by/4.0/). 